\title{
DAMPAK DISKRIMINASI PELAKSANAAN JADWAL PELAJARAN SEJARAH TERHADAP AKTIFITAS BELAJAR SISWA
}

\author{
Adela Siahaan \\ Prodi Sejarah Universitas Riau Kepulauan, Batam, Indonesia \\ delaningrat@gmail.com
}

\begin{abstract}
The research entitled the discrimination impact of history subject implementation toward students learning activity. This research used qualitative approach with case study method which did in SMA Negeri 14 Batam. Data collection techniques used observation and documentation of history learning; field notes, interviews with headmaster, vice-principal of curriculum, and students. Research results revealed that (1) discrimination that occurred in the implementation of history lesson because history subject just seen from the intellectual potential that is only the historical material. This causes history lesson is more often carried out during the daytime than science subject and the lessons which will be tested in national exam that dominated the schedule implementation in the morning (2) The implementation of schedule history in daytime causes students learning activity focused on listening and writing (3) The impact of discrimination implementation history schedule subject during daytime not just happen only for students but also the history teacher, that teacher are fatigue when teaching at daytime due to lack of history teacher at SMA negeri 14 Batam.
\end{abstract}

Keywords : Discrimination, schedule, History Education, Activity.

\section{Abstrak}

Penelitian ini berjudul dampak diskriminasi dari penerapan subjek sejarah terhadap aktivitas belajar siswa. Penelitian ini menggunakan pendekatan kualitatif dengan metode studi kasus di SMA Negeri 14 Batam. Teknik pengumpulan data menggunakan observasi dan dokumentasi pembelajaran sejarah; Catatan lapangan, wawancara dengan kepala sekolah, wakil kepala sekolah, dan siswa. Hasil penelitian menunjukkan bahwa (1) diskriminasi yang terjadi dalam pelaksanaan pelajaran sejarah karena subjek sejarah hanya dilihat dari potensi intelektual yang hanya merupakan bahan sejarah. Hal ini menyebabkan pelajaran sejarah lebih sering dilakukan pada siang hari daripada pelajaran sains dan pelajaran yang akan diuji dalam ujian nasional yang mendominasi pelaksanaan jadwal di pagi hari (2) Penerapan riwayat jadwal di siang hari menyebabkan aktivitas belajar siswa terfokus pada pendengaran. Dan menulis (3) Dampak dari jadwal pelaksanaan riwayat pelaksanaan diskriminasi selama siang hari tidak hanya terjadi hanya untuk siswa tapi juga guru sejarah, bahwa guru kelelahan ketika mengajar di siang hari karena kurangnya guru sejarah di SMA negeri 14 Batam.

Kata kunci: Diskriminasi, jadwal, Pendidikan Sejarah, Aktivitas.

\section{PENDAHULUAN}

Sebagaimana undang-undang sistem pendidikan nasional (UUSPN) NO.20 tahun 2003 menegaskan bahwa fungsi pendidikan yaitu mengembangkan kemampuan dan membentuk watak serta peradaban bangsa yang bermartabat dalam rangka mencerdaskan kehidupan bangsa 
(Sagala, 2009 :70). Pendidikan tidak bisa lepas dari sekolah dan jadwal pelajaran. Penjadwalan kegiatan belajar mengajar merupakan pengaturan perencanaan belajar mengajar yang meliputi mata pelajaran, guru, waktu dan tempat pada sekolah.

Pada umumnya di Indonesia, mata pelajaran yang masuk dalam Ujian Nasional (UN) dan mata pelajaran Ilmu Pengetahuan Alam (IPA) seperti Matematika, Bahasa Inggris, Bahasa Indonesia, Fisika, Kimia, dan Biologi mendominasi pelaksanaan jadwal pelajaran yang dilaksanakan saat pagi hari di sekolah. Diskriminasi adalah sikap berat sebelah dan tidak merata terhadap semua aspek. Namun hal ini berbeda dengan yang terjadi pada mata pelajaran sejarah yang merupakan bagian dari ilmu-ilmu sosial. Diskriminasi yang terjadi terhadap mata pelajaran sejarah pada jenjang pendidikan menengah yaitu mata pelajaran sejarah lebih sering dilaksanakan pada saat siang, terlebih setelah istirahat kedua di sekolah. Hal ini dikarenakan pendidikan masih dianggap sebagai pendidikan disiplin ilmu yang didasari oleh fakta, konsep, ketrampilan, teori dari disiplin ilmu itu. Pendidikan hanya dipandang dari potensi intelektual saja, padahal manusia diciptakan dari berbagai potensi. Jikalau itu menjadi landasan dalam pendidikan maka Ilmu Pengetahuan Alam (IPA) adalah primadonanya. Padahal manusia juga memiliki potensi lain seperti potensi emosi, potensi spiritual, potensi minat, potensi bermasyarakat, potensi kebudayaan, dan sebagainya. Orang lebih banyak memperhatikan materi dan disiplin sejarah dibandingkan kepentingan peserta didik dalam mata pelajaran sejarah (Hasan, 2012, 74-78).

Menurut Suparno (dalam Hasan, 2012 : 24) bahwa tujuan pendidikan sejarah menyangkut aspek-aspek kognitif dan afektif sehingga pendidikan sejarah tidak hanya ditujukan untuk kepentingan disiplin ilmu sejarah saja tetapi untuk tujuan pendidikan yang lebih luas. Pendidikan sejarah tidak boleh dikucilkan dari kehidupan keseharian siswa dan pelajaran sejarah harus dapat digunakan oleh siswa untuk kehidupan dirinya sebagai pribadi, anggota masyarakat, bangsa, hingga umat manusia. Hal ini senada dengan yang dikemukakan oleh Wiraatmadja (1992: 5) dalam disertasinya mengatakan pendidikan adalah transmisi nilai, sikap, dan pengetahuan dalam mengembangkan pribadi demi tercapainya kematangan dan kedewasaan karena pendidikan berfungsi sebagai transmisi budaya, peningkatan integrasi sosial atau bermasyarakat, mengadakan seleksi dan alokasi kerja melalui pendidikan itu sendiri. 
Diskriminasi yang terjadi terhadap pelaksanaan mata pelajaran sejarah juga terwakilkan pada SMA Negeri 14 Batam. Diskriminasi tersebut membuat aktifitas siswa cenderung pasif bahkan interaksi pembelajaran sejarah lebih dominan dilakukan oleh guru (teacher center). Konsentrasi siswa berkurang ketika menghadapi mata pelajaran sejarah karena otak sudah berpikir keras terhadap mata pelajaran sebelumnya yang didominasi oleh ilmu alam dan mata pelajaran yang akan diuji dalam Ujian Nasional (UN). Hal ini sesuai dengan teori belajar menurut Thorndike, belajar adalah proses interaksi stimulus dan respon. Stimulus yaitu apa saja yang dapat merangsang terjadinya kegiatan belajar seperti pikiran perasaan, atau ha-hal lain yang ditangkap panca indra. Sedangkan respon yaitu reaksi yang dimunculkan siswa ketika belajar, yang juga dapat berupa pikiran, perasaan atau tindakan (Budiningsih, 2012: 21). Stimulus yang dimaksud yaitu tentang jadwal pelajaran sejarah dan respon yaitu aktifitas siswa dalam mata pelajaran sejarah.

Menurut Sardiman (2010, 95-97) bahwa belajar itu melakukan aktifitas. Itulah sebabnya aktifitas merupakan prinsip yang sangat penting di dalam interaksi belajar mengajar. Dalam belajar itu sangat diperlukan adanya aktifitas, baik itu bersifat fisik ataupun mental yang saling berkaitan. Tanpa adanya aktifitas, proses belajar tidak mungkin berlangsung dengan baik. Menurut Paul B. Diedrich (dalam Sardiman, 2010 :101), aktifitas siswa tidak cukup hanya mendengarkan dan mencatat seperti yang lazim terdapat di sekolah, melainkan aktifitas siswa dapat digolongkan sebagai berikut :

a. Visual Activities (Kegiatan Visual) meliputi membaca, memperhatikan gambar demonstrasi, percobaan, mengamati.

b. Oral Activities (Kegiatan Lisan) meliputi menyatakan, merumuskan, bertanya, memberi saran, mengeluarkan pendapat, mengadakan wawancara, diskusi, interupsi.

c. Listening Activities (Kegiatan Mendengarkan) meliputi mendengarkan uraian atau penyajian bahan, mendengarkan percakapan, mendengarkan diskusi, mendengarkan musik, dan mendengarkan pidato.

d. Writing Activities (Kegiatan Menulis) meliputi menulis cerita, karangan, laopran, angket, menyalin, dan mengerjakan test.

e. Drawing Activities (Kegiatan Menggambar) meliputi menggambar, membuat grafik, peta, dan diagram. 
f. Motor Activities (Kegiatan Metrik) meliputi melakukan percobaan, membuat konstruksi, model mereparasi,bermain atau menyelenggarakan permainan.

g. Mental Activities (Kegiatan Mental) meliputi menanggapi, mengingat, memecahkan soal, menganalisis, melihat hubungan, serta mengambil keputusan.

h. Emotional Activities (Kegiatan Emosi) meliputi menaruh minat, merasa bosan, gembira, bergairah, berani, tenang, dan gugup.

Berdasarkan uraian di atas maka dilakukan penelitian untuk menganalisis bagaimana dampak diskriminasi pelaksanaan Jadwal Pelajaran Sejarah Terhadap Aktifitas Belajar Siswa.

\section{METODOLOGI PENELITIAN}

Metodologi yang digunakan dalam penelitian ini adalah penelitian kualitatif dengan menggunakan pendekatan studi kasus. Bogdan dan Taylor dalam L.J.Moleong (2006:4) mendefinisikan bahwa metode kualitatif sebagai prosedur penelitian yang menghasilkan data deskriptif berupa kata-kata tertulis atau lisan dari orang-orang dan perilaku yang dapat diamati. Studi kasus merupakan strategi penelitian yang peneliti menyelidiki secara cermat suatu program, peristiwa, aktifitas, proses, atau sekelompok individu-individu. Kasus dibatasi oleh waktu dan aktivitas, dan peneliti mengumpulkan informasi secara lengkap dengan menggunakan berbagai prosedur pengumpulan data berdasarkan waktu yang telah ditentukan (Stake dalam Creswell 2010 : 20). Berdasarkan semua pendapat di atas menggambarkan bahwa pendekatan studi kasus lebih menitik beratkan pada suatu kasus, kasus yang dimaksud dalam penelitian ini adalah dampak diskriminasi jadwal pelajaran sejarah terhadap aktifitas belajar siswa. Kasus tersebut dibatasi dalam suatu ruang lingkup yaitu kelas XI SMA Negeri 14 Batam. Teknik pengumpulan data meliputi observasi dan dokumentasi pembelajaran sejarah; catatan lapangan; wawancara kepada kepala sekolah, wakil kepala sekolah bidang kurikulum, serta siswa.

\section{HASIL PENELITIAN}

Berdasarkan hasil dokumentasi kalender akademik SMA Negeri 14 Batam dapat dideskripsikan bahwa mata pelajaran yang akan di uji dalam Ujian Nasional (UN) dan mata pelajaran Ilmu Pengetahuan Alam (IPA) seperti Matematika, Bahasa Inggris, Bahasa Indonesia, 
Fisika, Kimia, dan Biologi mendominasi pelaksanaan jadwal pelajaran yang dilaksanakan saat pagi hari di sekolah sedangkan mata pelajaran sejarah dilaksankan setelah istirahat pertama dan kedua diata jam 10 pagi. Hal ini dikarenakan mata pelajaran sejarah dipandang dari materi pelajarannya saja yang hanya untuk dihafal baik itu nama tokoh, waktu, dan tempat peristiwa terjadi.Seharusnya semua mata pelajaran yang ada dalam pendidikan tidak hanya dipandang dari potensi intelektualnya saja karena manusia juga memiliki potensi lain seperti potensi emosi, potensi spiritual, potensi minat, potensi bermasyarakat, potensi kebudayaan, dan sebagainya. Orang lebih banyak memperhatikan materi dan disiplin sejarah dibandingkan kepentingan peserta didik dalam mata pelajaran sejarah (Hasan, 2012, 74-78). Orang lebih banyak memperhatikan materi dan disiplin sejarah dibandingkan kepentingan peserta didik dalam mata pelajaran sejarah (Hasan, 2012, 74-78). Potensi yang dimiliki sejarah tidak hanya intelektual saja yaitu menghafal; melainkan ada potensi emosi dan bermasyarakat yaitu siswa dapat belajar dari teladan para pejuang bangsa mulai dari kegigihan, kepemimpinan, kesetiaan, dan karakter yang lain. Melalui pelajaran sejarah, siswa juga dapat menggali potensi kebudayaan yaitu siswa belajar awal terbentuknya etnik-etnik yang ada di Indonesia.

Selain itu hasil penelitian yang didapat dari SMA Negeri 14 Batam, baik itu observasi saat berlangsungnya pembelajaran sejarah hingga wawancara yang dilakukan kepada siswa maka didapati aktifitas yang dilakukan siswa saat pembelajaran sejarah sangat sedikit karena metode yang dilakukan guru dalam pembelajaran sejarah di siang hari hanyalah ceramah dan diskusi kelompok. Ketika kedua metode tersebut dilakukan maka aktifitas yang terjadi hanya mendengar dan menulis. Bahkan berdasarkan hasil wawancara dengan siswa, mereka menyatakan bahwa saat belajar sejarah di siang hari; kondisi fisik mereka sudah menurun dan otak terasa jenuh karena belajar pelajaran sebelumnya sehingga kadang-kadang membuat mereka mengantuk. Kondisi tersebut tidak terlepas dari pernyataan Thorndike mengenai belajar adalah proses interaksi stimulus dan respon. Stimulus yaitu apa saja yang dapat merangsang terjadinya kegiatan belajar seperti pikiran perasaan, atau hal lain yang ditangkap panca indra sedangkan respon yaitu reaksi yang dimunculkan siswa ketika belajar, yang juga dapat berupa pikiran, perasaan atau tindakan (Budiningsih, 2012: 21). Stimulus yang dimaksud pada kasus ini ialah penempatan pelaksanaan jadwal pelajaran sejarah di siang hari saat siswa sudah kelelahan mengahadapi pelajaran sebelumnya dan respon adalah aktifitas yang dilakukan oleh siswa yang 
hanya mendengar dan menulis saat pelajaran sejarah berlangsung. Padahal menurut Paul B. Diedrich (dalam Sardiman, 2010 :101), aktifitas siswa tidak cukup hanya mendengarkan dan mencatat seperti yang lazim terdapat di sekolah, melainkan aktifitas siswa dapat digolongkan antara lain Visual Activities (Kegiatan Visual), Oral Activities (Kegiatan Lisan), Listening Activities (Kegiatan Mendengarkan), Writing Activities (Kegiatan Menulis), Drawing Activities (Kegiatan Menggambar), Motor Activities (Kegiatan Metrik), Mental Activities (Kegiatan Mental).

Seharusnya semua aktifitas tersebut dapat dilakukan oleh siswa. Misalnya jika mengenai Drawing Activities (Kegiatan Menggambar) yang selama ini asumsi siswa bahwa itu hanya dimiliki mata pelajaran seni. Namun Drawing Activities (Kegiatan Menggambar) dalam sejarah dapat diterapkan dengan membuat peta-peta kuno. Pada mata pelajaran sejarah, Motor Activities (Kegiatan Metrik) dapat dilaksanakan seperti membuat candi-candi dari kerajaan-kerajaan Hindu Buddha yang ada di Indonesia. Penurunan aktifitas saat pembelajaran sejarah di siang hari tidak hanya dialami oleh siswa, melainkan juga guru sejarah. Berdasarkan wawancara dengan guru mata sejarah, sekolah tersebut hanya memiliki dua guru sejarah dengan jumlah mata pelajaran sejarah yang banyak karena pelajaran sejarah terbagi menjadi dua yaitu sejarah peminatan dan sejarah wajib guru sehingga guru mengalami kelelahan saat mengajar sejarah di saat siang hari.

\section{PENUTUP}

Berdasarkan Pembahasan hasil penelitian, dikriminasi yang terjadi pada pelaksanaan pelajaran sejarah karena mata pelajaran sejarah hanya dipandang dari potensi intelektualnya saja yaitu materi sejarah. Hal ini menyebabkan mata pelajaran sejarah di sekolah lebih sering dilaksanakan pada saat siang hari sedangkan mata pelajaran yang akan di uji dalam Ujian Nasional (UN) dan mata pelajaran Ilmu Pengetahuan Alam (IPA) mendominasi pelaksanaan jadwal pelajaran di pagi hari. Pelaksanaan jadwal sejarah di siang hari meyebabkan aktifitas siswa dalam belajar hanya mendengar dan menulis karena kondisi fisik mereka sudah menurun dan otak terasa jenuh setelah belajar pelajaran sebelumnya. Bahkan kadang-kadang membuat siswa mengantuk. Dampak dari diskriminasi pelaksanaan jadwal pelajaran sejarah di siang hari tidak hanya terjadi pada siswa tetapi juga guru sejarah yaitu guru mengalami kelelahan saat mengajar sejarah di saat siang hari karena sedikitnya guru sejarah di sekolah SMA Negeri 14 
sedangkan mata pelajaran sejarah yang terbagi dalam dua bagian yaitu sejarah peminatan dan sejarah wajib. Beberapa rekomendasi yang dapat diberikan berdasarkan hasil penelitian antara lain : Perhatian kepala sekolah juga diberikan kepada pelajaran sejarah dengan memberlakukan jadwal pelajaran sejarah di pagi hari, terutama bagi tingkatan kelas yang perlu mendapat perhatian serius. Selain itu kepada guru sejarah agar lebih menggunakan metode mengajar yang bervariasi ketika jadwal pelajaran dilaksanakan pada siang hari.

\section{DAFTAR PUSTAKA}

Budiningsih, Asri. (2012). Belajar dan Pembelajaran.Jakarta : Rineka Cipta

Cresswell, J.W. (2010). Research Desain : Pendekatan Kualitatif, Kuantitatif, dan Mixed. Yogyakarta : Pustaka Pelajar.

Hasan, Said Hamid. (2012). Pendidikan Sejarah Indonesia. Bandung : Rizqi.

Moleong, J.L. 2006. Metodologi Penelitian Kualitatif. Bandung : PT Rosdakarya

Sagala, Syaiful. (2009). Manajemen Strategik dalam Peningkatan Mutu Pendidikan. Bandung : Alfabeta

Sardiman, A.M. (2010). Interaksi dan Motivasi Belajar Mengajar. Jakarta : Rajawali Pers.

Wiriaatmadja. Rochiati. (1992). "Peranan pengajaran Sejarah Nasional Indonesia dalam Pembentukan Identitas Nasional”. Disertasi PPS IKIP Bandung : Tidak Diterbitkan. 